\title{
Achievement of Sustainable Transportation Through Land-Use Mix at Local Level: Case Studies of Two Urban Districts in Shiraz City, Iran
}

\author{
Tayebeh Saghapour ${ }^{1}$ \\ ${ }^{1}$ School of Art \& Architecture, Shiraz University, Shiraz, Iran \\ Correspondence: Tayebeh Saghapour, 215 Bell Street, Preston, VIC 3072, Australia. Tel: 61-470-183-816. \\ E-mail: T.saghapour@Gmail.com
}

Received: September 2, 2013

Accepted: October 6, 2013 Online Published: October 17, 2013

doi:10.5539/jsd.v6n11p71

URL: http://dx.doi.org/10.5539/jsd.v6n11p71

\begin{abstract}
In recent years, the concepts of sustainable development are discussed as the core of spatial planning around the world. Also, achieving these concepts is the ultimate goal in many kinds of planning. As it is known sustainable development will be approached when the same three objectives are realized; environmental protection, social justice and economic development. In today's world, it can be stated, excessive using of motor vehicles, especially in developing countries is one of the most influential factors on the environment. It is depending on type of arrangement and distribution of land uses in the cities. The findings of this paper, as an experimental study are explaining the impact of distribution and diversity of land uses on encouraging residents to use sustainable transportation modes. In this survey two districts of Shiraz metropolitan have been selected with similarity in demographic characteristics and differences in Land-use mix as the case study to compare. Basic data has been collected through 350 household questionnaires. Relationship between land-use mix and travel indicators, including the transportation mode and average trip length, has been done by statistical analysis (analysis of variance and correlation analysis). The results revealed that in areas with high rate of land-use mix the average length of vehicle trips by residents will be decreased. On the other hand, the usage of compatible vehicle with the environment increases. It can be concluded that appropriate policies in land use planning leads us to achieve sustainable transportation.
\end{abstract}

Keywords: land-use mix, trip length, sustainable transportation, compatible means of transport, Shiraz

\section{Introduction}

Nowadays, one of the urban planners and policy makers' main goals is to achieve sustainable transport in order to obtain a healthy and safe environment for citizens. Regarding sustainable transportation, main consideration is to control the demand for using private car by means of land use policies. Increased use of motor vehicles not only causes some problems such as traffic congestion, environmental pollution, etc. but also endangered people health. So that, there is a belief that even if the environmental results of the use of cars is limited, the problems related to traffic congestion and its reflections on the quality of life will still remain. Scattered communities with high dependency on automobiles, in many cities, have a significant impact on residents' lifestyle.

On the other hand, there is an interaction between land use planning and transportation. Land use activities affect transportation conditions, and transport planning impact on land use development. Land use pattern has a significant influence on accessibility, the way different uses distribute in the city and neighborhoods directly affect the decision, purpose of trips and type of travel pattern (Limnond \& Nimeier, 2004; Litman, 2013). While sustainable transport refers to the broad subject of transport that includes vehicles, energy, infrastructure, roads, railways, airways, waterways, canals, pipelines, and terminals. Also, it is largely being measured by transportation system effectiveness, efficiency, and environmental impacts of the system (Amekudzi, 2005). But in this paper, focus is on the vehicle aspect. So, this investigation has been just concentrated on how mix uses affect travel behavior in terms of mode share, non-motorized travel (walking and cycling) and average trip length. As transportation modes is one of the main pillars in achieving sustainable transport.

The last two decades, in Iran, have witnessed many studies base on the relationship between land use and public transportation. Most of these researches have been concentrated on finding land use factors which cause increase in the use of public transportation. In the city of Shiraz, in particular, some studies have been also conducted on the role of land use distribution on trip generation and the impacts of urban density on car dependency. One of 
the gaps in recent studies refers to the lack of investigation about the role of mixed use development on the use of non-motorized vehicles as a contributing factor to achieve sustainable transport.

In this regard, present study is to address how land use mix affects travel behavior in terms of increasing the number of walking and cycling trips. So, the hypotheses of this research are as follows:

a. There is a correlation between land use-mix and transport modes.

b. There is a correlation between land use-mix and the average of trip length.

\section{Literature Review}

The relationship between land use and travel pattern has been introduced for the first time in the U.S. After World War II both land use and travel patterns, changed in such a way that resulted in developing car-based cities. Increasing car ownership led to the dispersion patterns of development in cities. In this pattern of land uses, residents had to make long trips for daily activities which significantly increased fuel consumption as well as car dependency. So, the distance between homes, works, schools and shopping centers affected on the length of trips, especially in low-density and widespread cities. That would also make people more dependent on private cars and less interested in walking or cycling trips. In most cities, the main structure of the city has been shaped to encourage people for using more private cars in comparison with other modes.

On the other hand, in many cases, increasing the car ownership has encouraged residents to migrate to suburbs, in this way; they usually commuted between city centers and their living suburbs at least once a day. In fact, urban planning after World War II has been faced with a trend towards suburbs (Gaffikin \& Morrissey, 1999; Brehery, 1992). The consequences of this event were high-traffic congestion, pollution, noise and so on. At first, building new highways and increasing the capacity of streets, for a long time, proposed as ways to reduce traffic congestion (Maat, We,e \& Stead, 2005). Thereafter, planners started looking for broad scale plans for land use to solve environmental problems and issues. Also they attempted to replace the traditional methods with spatial planning and sought for the link between different aspects of economic, spatial and environmental (Tewdwr-Jones \& Williams, 2001). In order to come with such problems some kinds of policies related to land use mix, high residential density and smart growth have been discussed. These policies included Shaping Our Future, the Regional Development Strategy in 2025 and the Regional Transportation Strategy (RTS), which were raised In Northern Ireland (Belfast Metropolitan) between 2002 and 2012. Although, those projects were based on regional-scale for Belfast Metropolitan were set in smaller scale as well.

Land use-mix solutions are resulted in sustainable transport by modifying residents travel behaviors. Also, land use policies have important role in increasing the use of transport modes which are compatible with environment. In this way, the total number of trips or the total number kilometers of daily trips by motor vehicles are reduced.

According to Banister (1999) distribution of land uses in urban areas is one of the main reasons which cause automobile dependency. Spatial distribution of land uses including residential areas, official centers, and educational regions has a significant impact on the inefficiency of transportation networks (Zegras, 2004). While transport solutions concern the supply of transport infrastructure and traffic control systems, land use related solutions are about land use diversity and high density in a neighborhood or even an urban district. Distribution of activities will influence the number of trips with different transport modes and the relative ease of modes varies based on activities' location. So, mixing land uses can increase the use of non-motorized travel modes (Mahmoudi, 1994). In 2010, a study on public transit concening mixed use development with giving priority to walking, cycling and public transport has been carried out in the capital of Iran, Tehran. However, it is concluded that encouraging people to use puplic transport and walking or cycling in Tehran city needs some provision of facilities such as more efficient public transport, convinient pavements, secure pathes, etc. (Shahdoosti, 2011).

The adjustment of different uses and efficient positioning of activities is known as one way of reducing travel demand, travel mode choice and decision to make a trip is also influenced by several factors including socio-economic characteristics and distribution of land uses (Cervero, 2002; Jahanshahloo \& Amini, 2005). In fact, the distribution of major uses such as business centers, educational centers, recreational centers and service centers have significant impacts on travel demands especially by motor vehicles. In this regard, travel demand reduction is attainable by appropriate land use policies (Cervero \& Duncan, 2006; Ahmadi \& Moharamnejad, 2006).

There is a question about the possibility of obtaining sustainable transport through the reduction of motor vehicle in residential neighborhoods. Neighborhood characteristics also affect travel behavior through their influence on car ownership. There is also another possibility to reduce the amount of private car travel by designing a social 
and vital environment in neighborhoods. In this regard, it can be stated that land-use policies at local level play a key role in reducing driving (Aditijandra, Cao \& Mulley, 2012). In an experimental study in Stellenbosch, South Africa, implications of land use mix on the sustainability of African Urban Centers has been investigated. The study has demonstrated that the Land use mix index and Land use Frequency are essential indicators in discovering the mix of uses which is a main factor in achieving urban and transport sustainability (Musakwa \& Niekerk, 2012).

Policies that lead to increase the usage of environmental compatible means of transportation must be multi-dimensional ones. These policies should be contained several factors such as transport policies, governmental decisions and NGO's activities. So, with no coordination among these factors achievement to the policy' goals would be impossible and sustainable land use policies should be set in such ways that decrease the main traffic load. Walking and cycling as physical activities, not only improve public health but also is the most appropriate replacement for other modes within the cities specifically for short trips (Ewing, 2005; Santos \& Behrendt, 2010). A survey in 2010 was conducted in four urban districts of Shiraz city concerning the impact of land use mix on trip generation. The results shows that by developing mixed uses at local level the number of long trips will decrease (Soltani, Saghapour, Izadi, \& Pakshir, 2012).

As it has been previously addressed, transportation is a fundamental factor in the development of suburbs and development movement from cities to suburbs. In recent years, by increasing the car ownership traditional commute ways have been changed and distance has not been the influential factor in choosing place of living any more. A committee on Urban Environment of European countries in 1990, suggested highly dense cities as a solution to solve environmental problems, and proposed strategies with emphasis on the diversity of land-uses and services to meet daily needs especially at local levels. Studies show that the primary tool for improving the environment and the traffic congestion is to reduce the need of travel and ultimately reduce the length of trips within the city. Trip lengths are a function of both built environments and socioeconomic characteristics (Ewing \& Cervero, 2007). Mode choices have received the most intensive study over the decade. As Banister in 1998 suggested that in order to decrease car dependency and unnecessary trips, the planning must be applied to determine and implement the principles of sustainable development.

Thus, in the late 90's, in Europe, particularly in England, development of compact, dense cities with high level of land use mix in the local neighborhood became one of their policies (Banister, 1998). It can be stated that one of the common solutions to achieve sustainable transport is development of physical activities such as walking and cycling through developing compact cities while, the increase in low-density neighborhoods with car-based structure can mainly decrease the opportunities of physical activities by residents (Sallis, 2002; Humpel, 2002; Ewing, 2005).

In UK all issues related to the urban form, transportation, quality of life and long-term planning goals, including achieving sustainable development are compatible with the environment (Breheny, 1992). The issue contains three of the most important principles in transportation planning in the early 21 st century are as follows:

- How to allocate growth to households;

- How to restore and maintain urban viable;

- How to create sustainable urban environments.

According to Burton (2003) benefits of creating compact cities which are also associated with sustainability are as follows:

- Conservation and protection of the countryside suburbs;

- Less need to travel by car, and eventually saving in fuel consumption;

- Protection of public transport, walking and cycling;

- Improve accessibility to services and facilities;

- Increasing the efficiency of infrastructure facilities;

- Revitalization urban open spaces.

Through an empirical study in North America in 2000, Badoe and Miller concluded that land-use policies emphasizing higher traditional neighborhood design, urban densities, and mixed use development decreases auto ownership and use. This enhances more use of environmentally friendly modes of transit such as walking and cycling (Badoe \& Miller, 2000). 
Some urban planners who are known land use diversity as a means of achieving sustainable development believe that multi-purpose trips, efficient distribution of land-use and environmental protections lead to reduce trip generation. In worldwide researches, land-use mix is one of the most important and influential factor on reduction of car usage. Basic ideas in this field often have been based on increasing density; increasing appropriate environmental features to encourage walking and cycling and decline car dependency. Such theories contain non-traditional community, infill development and smart growth (Urban Land Institute, 2000; Newman \& Kenworthy, 1999; Calthorpe, 1993). In 2009, in a research by Ghorbani and Noshad, strategies and guidelines for conducting smart growth emphasizing on walking and cycling in the cities of Iran has been investigated. They concluded that as high density may lead to some problem such as pollution, increasing costs and etc. medium density in residential areas and neighborhoods can choose as the best way to cope with urban sprawl and promote the use of compatible means of transportation (Ghorbani \& Noshad, 2009). However, in an empirical study in Shiraz city, the relationship between urban density and car dependency was tested. The results reveal that increasing the density in neighborhoods will not lead to a reduction in car use (Soltani \& Etminani, 2010).

\section{Study Area Descriptions}

Shiraz city is divided into 9 municipality zones. Both study areas are located in municipality zone NO.1 which is one the biggest regions in the city of Shiraz. The area of this region is approximately a quarter of the area of Shiraz city. Its population is close to 185 thousand people (Consulting Engineers Farnahad, 2007). Figure 1 represents the location of two study areas in the city.

Table 1 shows the general characteristic of two study areas. Basic data has been collected through 350 household questionnaires. The questionnaires consisted of traffic characteristics of the household and the household' trip record of previous day. The method for determination of sample size was "simple random sampling" method. According to 2011 census (Statistical Center of Iran, 2011), there were 2900 households in the study areas; in this regard the sample size was estimated 350 households.

Table 1. Demographic information of the study areas (2012 Census)

\begin{tabular}{ccccc}
\hline & Population & Households & Family Size & $\begin{array}{c}\text { Density (people per } \\
\text { hectare) }\end{array}$ \\
\hline Molasadra & 5271 & 1294 & 4.1 & 119 \\
Ghodusi & 6770 & 1606 & 4.2 & 109 \\
\hline
\end{tabular}

According to the contents of Table 1, family size in Ghodusi is more than Mollasadra while the density in Mollasadra by 119 people per hectare is more than Ghodusi. 


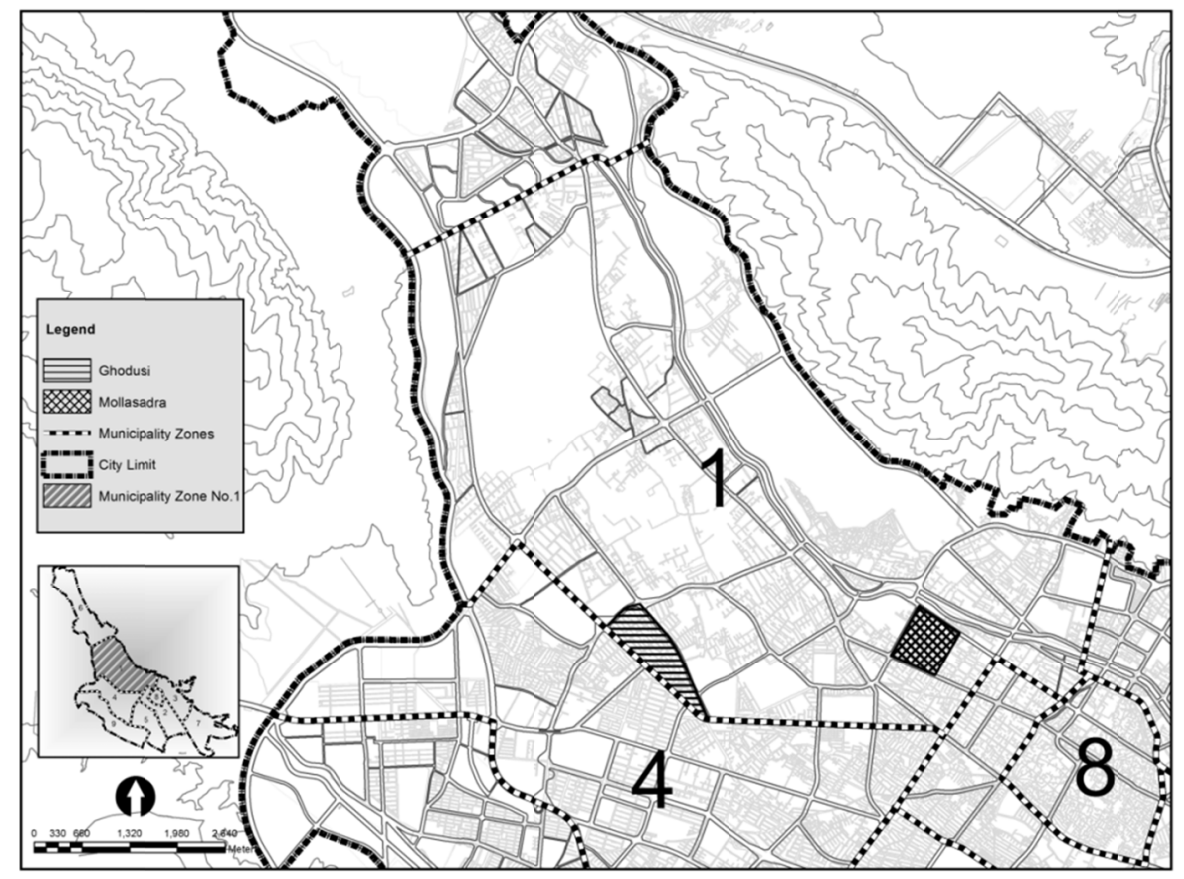

Figure 1. The map of location of the study areas in the municipality zone NO.1 and in the city (Consulting Engineers Farnhad, 2007)

\section{Methodology}

Daily travel data of two urban districts of Shiraz metropolitan were collected through questionnaires survey of totally 350 individuals to examine the link between land use mix and achieving sustainable transport at local level. In questionnaires respondents were asked to fill out their trip records of the day before sampling regarding the purpose of their trips and their modes of trips.

The data was from two residential districts with the same socio-economics features in the city of Shiraz (Mollasadra and Ghodusi) that were chosen due to their land-use mix entropy. The sample sizes have been determined regarding the number of households in each area including Mollasadra and Ghodusi that respectively 153 and 197 questionnaires were distributed to 350 of the total population size. It should be noted that confidence interval for the sample size determination was $5 \%$.

Another part of the data was extracted from existing databases including GIS maps of the Shiraz city (Department of City Planning, 2008) and census block information. In order to analyze the data Statistical Package for the Social Sciences (SPSS) has been used for investigating the relationship between variables on empirical observations.

\subsection{Variables and Parameters}

In order to measure the rate of diversity of land use in selected, land use-mix indicator has been measured. Transportation modes are considered in six categories: walking, taxi, private car, bus, motorcycle and bicycle.

Table 2 shows the portion of trips by different modes (mode share) in two study areas. Based on the information in Table 2 the portion of walking tours and bike trips in Mollasadra, respectively, were $35 \%$ and $7.1 \%$. Greater share of trips made by private car belongs to Ghodusi neighborhood by 51 percent. 
Table 2. Travel mode share within the study areas

\begin{tabular}{|c|c|c|c|c|c|c|c|c|c|c|c|c|c|c|}
\hline \multirow{3}{*}{ Districts } & \multicolumn{14}{|c|}{ Travel mode share } \\
\hline & \multicolumn{2}{|c|}{ Walking } & \multicolumn{2}{|c|}{ Taxi } & \multicolumn{2}{|c|}{ Private Car } & \multicolumn{2}{|c|}{ Bus } & \multicolumn{2}{|c|}{ Motorcycle } & \multicolumn{2}{|c|}{ Bicycle } & \multicolumn{2}{|c|}{ Total } \\
\hline & $\mathrm{N}$ & $\%$ & $\mathrm{~N}$ & $\%$ & $\mathrm{~N}$ & $\%$ & $\mathrm{~N}$ & $\%$ & $\mathrm{~N}$ & $\%$ & $\mathrm{~N}$ & $\%$ & $\mathrm{~N}$ & $\%$ \\
\hline Molasadra & 55 & 35 & 43 & 27.6 & 22 & 14.1 & 20 & 12.8 & 5 & 3.3 & 11 & 7.1 & 156 & 100 \\
\hline Ghodusi & 41 & 21.3 & 36 & 18.5 & 99 & 51 & 9 & 4.6 & 0 & 0 & 9 & 4.6 & 194 & 100 \\
\hline Total & 96 & 27.4 & 79 & 22.6 & 121 & 34.6 & 29 & 8.3 & 5 & 1.5 & 20 & 5.7 & 350 & 100 \\
\hline
\end{tabular}

Table 3. Average trip length within the study areas

\begin{tabular}{cc}
\hline Districts & Average trip length (minutes) \\
\hline Molasadra & 17 \\
Ghodusi & 25 \\
\hline
\end{tabular}

Contents of Table 3 indicate the average trip length (minutes) in study areas. The figures show that the average trip length in Ghodusi by 25 minutes is more than Mollasadra.

\subsection{Concepts}

1 Trip: Trip means handling and transporting people and goods from one place to another in a particular distance or interval that can involve trips by foot, bicycle, automobile, train, boat, airplane, or other means.

Land-use: is the human use of land. Land use involves the management and modification of natural environment or wilderness into built environment such as fields, pastures, and settlements. It also has been defined as "the arrangements, activities and inputs people undertake in a certain land cover type to produce, change or maintain it" (FAO, 1997a; FAO/UNEP, 1999)

Land-use Mix: Degree that related land uses (housing, commercial, institutional) are located together. Sometimes measures as Jobs/Housing Balance, the ratio of jobs and residents in an area (Litman, 2005). In other words, mixed-use is the rate of distribution and diversity of various land-uses, including residential, commercial, official, etc. and it is calculated as follows:

$$
\begin{gathered}
\text { Land-Use Mix Entropy }=[\% \text { of Residential } \times \log (\% \text { of Residential })]+[\% \text { of Retail and Services } \times \\
\log (\% \text { of Retail and Services })]+[\% \text { of Office } \times \log (\% \text { of Office })]+[\% \text { of Manufacturing } \times \log (\% \\
\text { of Manufacturing })]+[\% \text { of Community Services } \times \log (\% \text { of Community Services })]+[\% \text { of } \\
\text { Recreation } \times \log (\% \text { of Recreation })] / \log (k)
\end{gathered}
$$

In the Formula (1), ' $k$ ' represents the number of land use categories in the scale of study. The result of equation after normalizing is a number between 0 and 1 . If the result number is 1 , it means that there is the highest range of land-use mix in the districts and as it gets closer to 0 , means that there is less mixed-uses in the area. It should be stated that in this method the quantity of land-uses are just considered, not the quality. So, according to Equation (1) land-use mix entropy and standardized land-use mix entropy has been computed for both areas which are shown in Table 4.

Table 4. Land-use mix entropy and standardized land-use mix entropy of study areas

\begin{tabular}{ccc}
\hline & Land-use mix entropy & Standardized land-use mix entropy \\
\hline Molasadra & 258.8 & 0.85 \\
Ghodusi & 238.1 & 0.27 \\
\hline
\end{tabular}

According to Table 4, from two study areas Mollsadra, by 0.85 standardized land-use mixes entropy is the neighborhood with high rate of diversity in activities and uses. In contrary, Ghodusi by 0.27 mixed uses entropy is the neighborhood with low diversity. 


\subsection{Conceptual Model of Research}

Based on the literature review it is expected that land-use mix impacts on trip variables such as transport mode choice and average travel length. Figure 2 presents the research framework of the study.

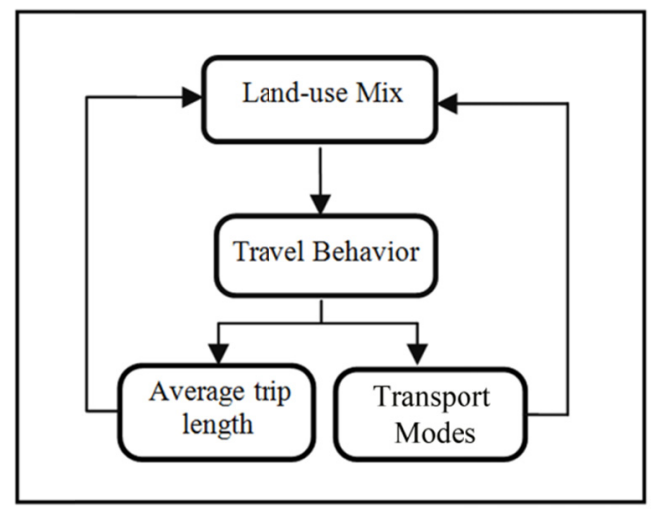

Figure 2. Conceptual model for research

\section{Analyses and Results}

In this part the relationship between variables has been tested based on the data extracted from questionnaires.

\subsection{Analysis of Variance}

To assess the impact of mixed uses in study areas on Travel behavior in terms of transport mode choice and average trip length, one way analysis of variance (ANOVA) was computed. In fact, the significance of this analysis is in the unique features and characteristics of study areas that were hypothesized to cause the difference in the mentioned factors. As can be seen two study areas have been significantly different in terms of average trip length and transport mode choice:

$\mathrm{F}_{\text {average trip length }}(320,30)=3.477, \mathrm{p}=.000$

$F_{\text {travel modes }}(344,6)=5.202, \mathrm{p}=.000$

The higher value of F-statistic in the analysis of the differences between study areas indicates more differences due to travel mode choice and average trip length within those regions.

Table 5. Summary of analysis of variance

\begin{tabular}{llclccc}
\hline ANOVA & & Sum of squares & df & Mean square & F & Sig. \\
\hline \multirow{2}{*}{ The average } & Between groups & 125.614 & 30 & 4.187 & 3.477 & .000 \\
length of trip & Within groups & 385.315 & 320 & 1.204 & & \\
& Total & 510.929 & 350 & & & \\
& Between groups & 42.499 & 6 & 7.083 & 5.202 & .000 \\
\multirow{3}{*}{ Travel modes } & Within groups & 468.430 & 344 & 1.362 & & \\
& Total & 510.929 & 350 & & & \\
\hline
\end{tabular}

From the contents of Table 5 can be concluded that there are significant differences between the two variables in both areas.

\subsection{Correlation Analysis}

To understand the relationship between the independent and dependent variables, bivariate correlation analysis was used. For, controlling the influence of other variables on the correlation results, partial correlation analysis has been used as well.

Due to variable's type correlation analysis used for nominal and ordinal variables should be different. Pearson and Spearman correlation analysis is used for quantitative variables and for nominal variables, Kendall 
correlation analysis is applied. In this regard, as the variable of average trip length was a quantitative variable, Pearson correlation was run.

Table 6. Summary of correlation analysis between land-use and average trip length

\begin{tabular}{ccc}
\hline & & Average trip length \\
\hline & Pearson Correlation & $-0.704(* *)$ \\
Land-use mix index & Sig. (2-tailed) & .000 \\
& $\mathrm{~N}$ & 350 \\
\hline
\end{tabular}

Figures in Table 6 show the summary of correlation analysis between average trip length and land-use mix index (at confidence level of 99\%). As seen the Pearson correlation in a negative number. This means that by increasing the land-use diversity in areas, the average trip length will be reduced.

Table 7. Summary of correlation analysis between land-use mix and travel modes

\begin{tabular}{ccccccc}
\hline $\begin{array}{c}\text { Quantitative } \\
\text { variable }\end{array}$ & $\begin{array}{c}\text { Nominal } \\
\text { variable }\end{array}$ & Correlation & Value & $\begin{array}{c}\text { Asymp. Std. } \\
\text { Error(a) }\end{array}$ & $\begin{array}{c}\text { Approx. } \\
\text { T(b) }\end{array}$ & $\begin{array}{c}\text { Approx. } \\
\text { Sig. }\end{array}$ \\
\hline Land-use mix & Travel mode & $\begin{array}{c}\text { Kendall's } \\
\text { tau-b } \\
\mathrm{N}\end{array}$ & $\begin{array}{c}0.123 \\
350\end{array}$ & 0.040 & 3.050 & 0.002 \\
\hline
\end{tabular}

Since trip mode choice was a nominal variable, Kendall correlation has been applied. The results are summarized in Table 7. There is a positive correlation between the two variables of land use diversity and type of vehicle travel.

It should be noted that walking and cycling as compatible means of transportation are indicated by code 1 while code 2 is allocated to motor vehicles. For better understanding of the relationship between travel mode choice and standardized land use mix entropy, crosstabs analysis has been used.

Table 8. Crosstabs analysis between land-use mix and transport modes

\begin{tabular}{cccccc}
\hline & \multicolumn{4}{c}{ Travel Mode } \\
\cline { 2 - 6 } & & \multicolumn{2}{c}{$\begin{array}{c}\text { Compatible with } \\
\text { environment }\end{array}$} & Motor vehicle \\
\cline { 2 - 6 } & 0 & 1 & Percent & $\mathrm{N}$ & Percent \\
\hline & .1 & 3 & 2.8 & 13 & 5.3 \\
& .2 & 5 & 4.7 & 3 & 6.6 \\
Standardized land-use & .3 & 7 & 6.5 & 19 & 1.2 \\
mix index & .4 & 8 & 7.5 & 4 & 1.6 \\
& .5 & 9 & 8.4 & 26 & 10.7 \\
& .6 & 10 & 9.3 & 10 & 4.1 \\
& .7 & 10 & 9.3 & 28 & 11.5 \\
& .8 & 16 & 15 & 43 & 17.7 \\
Total & .9 & 19 & 17.8 & 27 & 11.1 \\
& 1 & 19 & 17.8 & 54 & 22.2 \\
& & 107 & 100 & 243 & 100 \\
\hline
\end{tabular}

As shown in Table 8, when the diversity of land-use increases the usage of compatible means of transportation goes up. On the other hand, contrary to what is expected, higher rate of mixed-use development will not decrease the usage of motor vehicles. 


\section{Disscusion}

According to the results of analyses the variable of average trip length negatively correlated with land use mix entropy. It means that by increasing the mixed uses in neighborhoods the average trip length will reduce. Moreover, for investigating the relationship between travel modes as a nominal variable with land use mix entropy crosstabs analysis has been run. The results show that by developing mixed uses in neighborhoods the number of walking and cycling trips rises.

Nevertheless, the empirical evidence concerning the role of mixing uses on modes usage (the use of non-motorized modes) is not as expected. In contrast to the results of previous studies, through this survey it cannot be supported that by increasing the share of non-residential activities the use of motor vehicle will decrease. In fact, more accessibility to local facilities may not be a good encouragement for not using private cars.

\section{Conclusions}

This survey is not seeking to attempt a grand study to measure all the relationships between land use mix and travel behaviors. It is simply seeking to realize the point that if people encourage making more non-motorized trips by increasing mixed uses in residential areas at local level. Also, obtaining more accurate result require to define more variables which can affect travel behavior.

According to theoretical studies in literature review; the results in this paper were not completely similar to the studies in other countries in the world especially developed ones. The probable reason of this consequence can be referred to some reasons including the weakness of infrastructural facilities in public transportation, socio-economic characteristics which are assumed to be constant in this study, and cultural features. Iran as a developing country, have some specific cultural and social background which can be directly impact on people's travel behaviors. For instance, using public transportation as a travel mode choice is socially rejected by households with medium to high average income level in society. Thus, although Mollasadra as a district with high rate of land-use mix and well equipped with facilities and services has more trips on foot than Ghodusi, it has also more rate of trips by private cars.

It can be concluded that in order to obtain more success in achieving sustainability, incentive policies should be made to encourage people to use public transportation or environmental compatible modes for commuting.Therefore, in future studies, it seems necessary to measure socio-economic features and consider cultural characteristics as influential factors on travel patterns.

\section{References}

Aditjandra, P., Cao, X., \& Mully, C. (2012). Understanding neighborhood design impact on travel behavior: An application of structural equations model to a British metropolitan data. Transportation Research Part A, 46(1), 22-32. http://dx.doi.org/10.1016/j.tra.2011.09.001

Ahmadi, M, \& Moharramnejad, N. (2007). Sustainable management of urban transport and its approaches. Proceeding of Third Regional Conference on Traffic Management. Retrieved from http://www.civilica.com/Paper-RCTM03-RCTM03_023.html

Amekudzi, J. (2005). Addressing Sustainability in Transportation Systems: Definitions, Indicators, and Metrics. Infrastructure Systems, 11(1), 31-50. http://dx.doi.org/10.1061/(ASCE)1076-0342(2005)11:1(31)

Amini, E., \& Jahanshahloo, L. (2007). Urban planning and its role in achieving sustainable urban transport. Seventh Conference on Transportation and Traffic Engineering. Retrieved from http://www.civilica.com/Paper-TTC07-TTC07_024.html

Banister, D. (1998). Transport Policy and the Environment. London: Spon. http://dx.doi.org/10.4324/9780203235652

Banister, D., Button, K., \& Nijkamp, P. (1999). Environment, Land Use and Urban Policy. Cheltenham: Edward Elgar.

Badoe, D., \& Miller, E. (2000). Transportation-land-use interaction: empirical findings in North America, and their implications for modeling. Transportation Research Part D: Transport and Environment, 5(4), 235-263. http://dx.doi.org/10.1016/S1361-9209(99)00036-X

Brehery, M. (1992). Sustainable Development. Great Britain: Pion Limited.

Burton, E. (2003). Housing for an urban renaissance: Implications for social equity. Housing Studies, 18, 537-562. http://dx.doi.org/10.1080/02673030304249 
Calthorpe, P. (1993). The next American Metropolis: Ecology, Community, and the American Dream. New York: Princeton Architectural Press. Retrived from $\mathrm{http} / /$ books.google.com.au/books?id=WtKU5L0ajA8C\&printsec=frontcover $\# \mathrm{v}=$ onepage $\& \mathrm{q} \& \mathrm{f}=$ false

Cervero, R. (2002). Built environments and mode choice. Transport and environment, 7(4), 265-284. http://dx.doi.org/10.1016/S1361-9209(01)00024-4

Cervero, R., \& Duncan, M. (2006). Which Reduces Vehicle Travel More: Jobs-Housing Balance or Retail-Housing Mixing? American Planning Association, 72(4), 475-490. http://dx.doi.org/10.1080/01944360608976767

Consulting Engineers Farnhad. (2007). Detailed report on Shiraz Detailed Plan, a series of basic studies, commissioned by the Department of Architecture and Urban Planning, Shiraz, Iran.

Department of City Planning, Iran, Shiraz Municipality. (2008). Retrieved from http://www.eshiraz.ir/planning

Ewing, R. (2005b). Can the physical environment determine physical activity levels? Exercise and Sport Science Reviews, 33(2), 69-75. Retrieved from www.ncbi.nlm.nih.gov/pubmed/15821427

Ewing, R., \& Cervero, R. (2007). Travel and the built environment: a synthesis. Transportation Research Record, 1780, 87-114. http://dx.doi.org/10.3141/1780-10

Gaffikin, F., \& Morrissey, M. (1999). City Visions: Imagining Place, Enfranchising People. London: Pluto.

Ghorbani, R., \& Noshad, S. (2009). Smart Growth Principles and Strategies of Urban Development, Journal of Geographic and Development, 12, 163-180.

Humpel, N., Owen, N., \& Leslie, E. (2002). Environmental Factors Associated with Adults' Participation in Physical Activity: A Review. American Journal of Preventive Medicine, 22(3), 188-199. http://dx.doi.org/10.1016/S0749-3797(01)00426-3

IPCC Special Report on Land Use, Land-Use Change and Forestry, 2.2.1.1 Land Use. Retrieved from http://www.grida.no/publications/other/ipcc_sr/?src=/climate/ipcc/land_use/045.htm

Limnond, T., \& Nimeier, D. (2004). Effect of land use on decisions of shopping tour generation. Transportation, 31(2), 153-181. http://dx.doi.org/10.1023/B:PORT.0000016578.21486.af

Litman, T. (1999). Traffic Calming Benefits, Costs and Equity Impacts. Victoria Transport Policy Institute 3. Retrieved from www.vtpi.org/calming.pdf

Litman, T. (2005). Land Use Impact on Transport, How Land Use Factors Affect Travel Behavior. Victoria Transport Policy Institute. Retrieved from www.dot.wisconsin.gov/localgov/docs/victoria-transport.pdf

Litman T. (2013). Land Use Impact on Transport, How Land Use Factors Affect Travel Behavior. Victoria Transport Policy Institute with Rowan Steele. Retrieved from http://www.vtpi.org/landtravel.pdf

Maat, K., We,e B., \& Stead, D. (2005). Land use and travel behavior: expected effects from the perspective of utility theory and activity-based theories. Environment and Planning B: Planning and Design, 32(1),33-44. http://dx.doi.org/10.1068/b31106

Mahmoodi, A. (1994). Land use and urban transport. Geographic Research, 33(2), 91-92.

Mousa Dashti, H. (1998). A study of the feasible relationship between travel behavior and land use patterns: A case study of Montgomery County, Pennsylvania. Dissertations available from ProQuest. Paper AAI9829881. Retrieved from http://repository.upenn.edu/dissertations/AAI9829881

Musakwa, W., \& Niekerk, A. (2012). Implications of Land Use Mix on the Sustainability of African Urban Centres: A Case Study of Stellenbosch, South Africa. Proceedings of 17th International Conference on Urban Planning, Regional Development and Information Society, Vienna, Austria. Retrieved from http://hdl.handle.net/10019.1/84355

Newman, P. W. G., \& Kenworthy, J. R. (1999). Sustainability and Cities: Overcoming Automobile Dependence. Washington DC: Island Press.

Sallis J. F., \& Owen, N. (2002). Health Behavior and Health Education: Theory, Research and Practice. San Francisco, CA: Jossey-Bass.

Santos, G., Behrendt, H., \& Telteyboym, A. (2010). Policy instruments for sustainable road transport. Research in Transportation Economics, 28(1), 46-91. http://dx.doi.org/10.1016/j.retrec.2010.03.002 
Shahdoosti, G. (2011). New Urbanism and Transport Oriented Development (TOD), proceeding of $10^{\text {th }}$ Conference on Traffic and Transportation. Retrieved from http://www.civilica.com/Paper-TTC09-TTC09_073.html

Soltani, A., \& Etminani Ghasrdashti, R. (2010). The Impact of Urban Density on Car Dependency, a Case Study of Three Residential Districts of Region 1, Shiraz. Urban-Regional Studies and Research, 2(5), 139-154. Retrieved from http://uijs.ui.ac.ir/urs/browse.php?mag_id=5

Soltani, A., Saghapour, T., Izadi, H., \& Pakshir, A. (2012). Trip generation and its relationship with land use diversity: Case studies of four urban districts in Shiraz metropolitan area. Urban-Regional Studies and Research, 3(12), 1-16. Retrieved from http://uijs.ui.ac.ir/urs/browse.php?mag_id=12

Statistical Center of Iran, Census Block Information. (2011). Retrieved from http://www.amar.org.ir/Portals/1/Iran/census-2.pdf

Tewdwr-Jones, M., \& Williams, H. R. (2001). The European dimension of British planning. New York: Spon Press, 73(3), 361-368. http://dx.doi.org/10.3828/tpr.73.3.7

Zegras P. (2004). The influence of land use on travel behavior: empirical evidence from Santiago de Chile. Transportation Research Board (TRB), 83th Annual Meeting. Washington, D.C.

\section{Copyrights}

Copyright for this article is retained by the author(s), with first publication rights granted to the journal.

This is an open-access article distributed under the terms and conditions of the Creative Commons Attribution license (http://creativecommons.org/licenses/by/3.0/). 